\title{
PERJANJIAN PERKAWINAN YANG MENGATUR TANGGUNG JAWAB TERHADAP ANAK LUAR KAWIN DALAM PERSPEKTIF HUKUM ISLAM: ANALISIS AKTA PERJANJIAN PERKAWINAN
}

\author{
Nazla \\ Abstrak
}

The children whom born outside of marriage can become trustworthiness of his /her mother's husband only if it has his consent and be noticed at marital agreement. It has abided by one of contract on Islamic law principles that 's recognized as voluntary. In the marital agreement might to be acquiesced that the children whom born outside of marriage will receive funds for his/her education and living costs. But in that agreement does not mention the name of the children to be clearer to who will get the funds giving for. More over the agreement does not say regarding else gifts to be father's responsibility. To anticipate under Islamic law principles which said that the children have no patrimony portions then can be created escrow grant by last will or gift method's from his/her father.

Kata kunci: hukum islam, perjanjian kawin, analisis, tanggungjawab, anak luar kawin,

\section{Pendahuluan}

Sahnya suatu perkawinan menurut UUP diatur dalam Pasal 2 ayat (1). yaitu perkawinan adalah sah apabila dilakukan menurut hukum masingmasing agamanya dan kepercayaannya. Penjelasan Pasal tersebut menyebutkan bahwa:

Dengan perumusan di luar hukum masing-masing agamanya dan kepercayaannya itu. sesuai dengan Undang-Undang Dasar 1945. Yang dimaksud dengan hukum masing-masing agamanya dan kepercayaannya itu termasuk ketentuan yang berlaku bagi golongan agamanya dan kepercayaannya itu sepanjang tidak bertentangan atau tidak ditentukan lain dalam Undang-Undang ini. $^{\prime}$ 
Akibat Hukum dari suatu perkawinan yang sah adalah timbulnya hubungan hukum antara suami dan isteri. antara orang tua dan anak. antara wali dan anak dan yang terakhir adalah mengenai harta benda dalam perkawinan.

Menurut R. Subekti. jika seorang yang hendak kawin mempunyai benda-benda yang berharga atau mengharapkan akan memperoleh kekayaan misalnya suatu warisan. maka adakalanya diadakan perjanjian perkawinan (huwelijksvoorwaarden). ${ }^{2}$ Bagi masyarakat yang tunduk pada Kitab UndangUndang Hukum Perdata maka berlaku ketentuan Pasal 119 yaitu ketika terjadi perkawinan maka terjadi persatuan harta suami isteri kecuali ditentukan lain dalam perjanjian kawin. Perjanjian perkawinan menurut KUHPerdata harus dibuat oleh notaris dan tercantum dalam akta perjanjian perkawinan dan dibuat sebelum perkawinan berlangsung. sebagaimana diatur dalam Pasal 147 KUHPerdata. UUP mengatur perjanjian perkawinan dalam Pasal 29 ayat (1), yang mengatur bahwa:

Pada waktu atau sebelum perkawinan dilangsungkan. kedua pihak atas persetujuan bersama dapat mengadakan perjanjian tertulis yang disahkan oleh Pegawai Pencatat Perkawinan. setelah mana isinya berlaku juga terhadap pihak ketiga sepanjang pihak ketiga tersangkut.

Pasal 45 Kompilasi Hukum Islam mengatur bahwa:

Kedua calon mempelai dapat mengadakan perjanjian perkawinan dalam bentuk:

a) Taklik talak: dan

b) Perjanjian lain yang tidak bertentangan dengan hukum Islam.

UUP tidak menegaskan perjanjian perkawinan harus dibuat dengan akta notaris. melainkan dapat dilakukan di bawah tangan dengan disahkan oleh pegawai pencatat pernikahan. Begitu juga Kompilasi Hukum Islam tidak menegaskan perjanjian harus dibuat dengan akta notaris. tetapi dapat dibuat di bawah tangan dengan disahkan Pegawai Pencatat Pernikahan. Maka. bagi perkawinan yang dilakukan oleh calon suami isteri yang

1 Endang Sumiarni, "Kedudukan Suami Istri dalam Hukum Perkawinan”, hal. 8. mengutip Asmin. Status Perkawinan Antar Agama. (Jakarta: Dian Rakyat, 1998), hal. 16.

2 Subekti. "Pokok-Pokok Hukum Perdata”. (Jakarta: PT Intermasa. 1993), hal. 37. 
beragama Islam tentu akan tunduk pada peraturan tersebut. Bagaimana jika ingin membuat perjanjian pernikahan dengan akta notaris.

Uraian latar belakang tersebut menunjukkan beberapa permasalahan yang timbul mengenai anak luar kawin. yang akan dijelaskan dalam tulisan ini adalah:

1. Dapatkah anak luar kawin menjadi tanggung jawab suami seluruhnya yang dimuat dalam perjanjian perkawinan terlebih dahulu?

2. Bagaimana menentukan hak anak luar kawin dalam akta perjanjian perkawinan menurut Hukum Islam?

II. Perjanjian Perkawinan Yang Mengatur Tanggung Jawab Terhadap Anak Luar Kawin Dalam Perspektif Hukum Islam Analisis Akta Perjanjian Perkawinan

\section{A. Pengertian Perkawinan}

Salah satu fase yang dilewati oleh manusia dalam siklus hidupnya adalah perkawinan. Oleh karena itu. pengaturan mengenai perkawinan sudah ada sejak manusia itu turun ke bumi. Perkawinan merupakan tuntutan naluriah manusia untuk berketurunan guna kelangsungan hidupnya dan untuk memperoleh ketenangan hidup serta menumbuhkan dan memupuk rasa kasih sayang insani. ${ }^{3}$ Al-Qur'an banyak mengatur mengenai perkawinan dalam ayat-ayatnya. Sebagaimana dalam QS Yasin (36):36, sebagai berikut:

Maha suci Tuhan yang telah menciptakan pasangpasangan semuanya. baik apa yang ditumbuhkan oleh bumi dan diri mereka. maupun dari apa yang tidak merekaketahui.

Perkawinan menimbulkan ketenangan hidup manusia dan menumbuhkan rasa kasih sayang. sebagaimana dalam QS arRuum(30):21, yang artinya sebagai berikut:

Dan diantara tanda-tanda kekuasaan-nya. Dia menciptakan untuk kamu istri-istri dari jenismu sendiri

${ }^{3}$ Ahmad Azhar Basyir, "Hukum Perkawinan Islam", (Yogyakarta: UII Press, 1999), hal. 12. 
supaya kamu cenderung dan merasa tenteram kepadanya dan dijadikan-Nya rasa kasih sayang diantara kamu..."

Perkawinan dalam bahasa Arab disebut dengan al-nikah yang bermakna al-wathi' dan al-dammu wal al tadakhul. Terkadang juga disebut dengan al-dammu wa al-jam 'u atau 'ibarat 'an al-wath' wa al' $a q$ yang bermakna bersetubuh. berkumpul dan akad. ${ }^{4}$ Menurut Wahbah al-Zuhaily perkawinan adalah:

Akad yang telah ditetapkan oleh syari' agar seorang lakilaki dapat mengambil manfaat untuk melakukan istimta'(persetubuhan) dengan seorang wanita atau sebaliknya. ${ }^{5}$

Menurut Hanafiah, nikah adalah:

Akad yang memberi faedah untuk melakukan mut'ah secara sengaja". Artinya kehalalan seorang laki-laki untuk beristimta' dengan seorang wanita selama tidak ada faktor yang menghalangi sahnya pernikahan tersebut secara syar'i.

Menurut Ahmad Azhar Basyir. perkawinan menurut hukum Islam adalah: ${ }^{6}$

Suatu akad atau perikatan untuk menghalalkan hubungan kelamin antara laki-laki dan perempuan dalam rangka mewujudkan kebahagiaan hidup keluarga yang diliputi rasa ketentraman serta kasih sayang dengan cara yang diridhai Allah.

Akan tetapi perkawinan tidak hanya merupakan ikatan untuk menghalalkan hubungan kelamin lawan jenis. Ada yang mengikuti hubungan itu yaitu tanggung jawab terhadap isteri. suami. anak. Ada hubungan hukum yang timbul dari perkawinan itu.

${ }^{4}$ Wahbah Zuhaily, al-Fiqh al-Islami Wa Adilatuhu dalam Amir Nuruddin dan Azhari Akmal Tarigan. "Hukum Perdata Islam Di Indonesia Studi Kritis Perkembangan hukum Islam dari fikih, UU no 1/1974 sampai KHI”. (Jakarta:Kencana. 2004). hal. 38.

\footnotetext{
${ }^{5}$ Ibid., hal. 39 .

${ }^{6}$ Op. Cit.. hal. 12.
} 
Sebagaimana menurut Muhammad Abu Zahrah didalam kitabnya al-ahwal al-syakhsiyyah. mendefinisikan nikah sebagai:

Akad yang menimbulkan akibat hukum berupa halalnya melakukan persetubuhan antara laki-laki dengan perempuan. saling tolong-menolong serta menimbulkan hak dan kewajiban diantara keduanya.

UUP dalam Pasal 1 mendefinisikan perkawinan sebagai berikut

Perkawinan ialah ikatan lahir batin antara seorang pria dan seorang wanita sebagai suami isteri dengan tujuan membentuk keluarga yang berbahagia dan kekal berdasarkan Ketuhanan Yang Maha Esa.

Definisi perkawinan menurut KHI dalam Pasal 2 adalah

Akad yang sangat kuat atau miitsaaqan ghaliidan untuk mentaati perintah Allah dan melaksanakannya merupakan ibadah.

Perkawinan yang sah menurut Pasal $4 \mathrm{KHI}$ adalah apabila dilakukan menurut Hukum Islam sesuai dengan pasal 2 ayat (1) UUP. Pasal $5 \mathrm{KHI}$ mengatur agar terjamin ketertiban perkawinan bagi masyarakat Islam setiap perkawinan harus dicatat. Dari kedua pasal tersebut. jelas menurut KHI perkawinan yang sah yaitu perkawinan yang dilangsungkan menurut agama Islam dan dicatat oleh Pegawai Pencatat Perkawinan. Jadi perkawinan adalah suatu ikatan lahir batin antara seorang pria dan seorang wanita yang yang menimbulkan hak dan kewajiban bagi keduanya bertujuan membentuk keluarga bahagia dan sejahtera berdasarkan Ketuhanan Yang Maha Esa. Perkawinan yang sah menimbulkan hubungan hukum antara suami dan isteri. antara orang tua dan anak. antara wali dan anak dan yang terakhir adalah mengenai harta benda dalam perkawinan.

${ }^{7}$ Muhammad Abu Zahrah, al Ahwal al Syakhisiyyah dalam Amir Nuruddin dan Azhari Akmal Tarigan, "Hukum Perdata Islam di Indonesia studi kritis perkembangan Hukum Islam dari Fikih, UU No.1 tahun 1974 sampai KHI”, (Jakarta:Kencana, 2004), hal. 39. 
B. Pengertian Perjanjian Perkawinan

\section{Menurut KUH Perdata dan UUP}

Sebelum membahas pengertian perjanjian perkawinan. terlebih dulu membahas pengertian perjanjian pada umumnya.

Pengaturan mengenai perjanjian pada umumnya diatur dalam KUHPerdata Pasal 1313 disebutkan:

Perjanjian adalah suatu perbuatan dimana suatu orang atau lebih mengikatkan dirinya terhadap satu orang atau lebih.

Perjanjian merupakan suatu peristiwa yang menimbulkan suatu perbuatan hukum yaitu perikatan. Dari definisi tersebut terkandung unsur-unsur sebagai berikut: ${ }^{8}$

a) Adanya hubungan hukum;

b) Biasanya mengenai kekayaan atau harta benda;

c) Antara dua orang atau lebih;

d) Memberikan hak kepada pihak yang satu;

e) Meletakkan kewajiban pada pihak lain;

f) Adanya prestasi.

Jadi perjanjian merupakan suatu hubungan hukum yang menjamin pihak-pihak yang bersangkutan haknya dijamin dan dilindungi oleh hukum dan undang-undang sehingga apabila tidak dipenuhi secara sukarela. dia berhak menuntut melalui pengadilan supaya orang yang bersangkutan dipaksa untuk memenuhi atau menegakkan haknya. ${ }^{9}$

Perjanjian perkawinan sendiri diatur dalam buku I tentang orang. Jadi perjanjian perkawinan menurut KUHPerdata berbeda dengan perjanjian yang diatur dalam Pasal 1313 KUHPerdata. Perjanjian perkawinan dalam KUHPerdata diatur dalam Pasal 139 yaitu:

Dengan mengadakan perjanjian perkawinan. kedua calon suami isteri adalah berhak menyiapkan

${ }^{8}$ I G Rai Widjaja. "Merancang Suatu Kontrak Contract Drafting Teori dan Praktik". (Jakarta: Kesaint Blanc, 2003), hal. 21.

"Ibid.. hal. 23. 
beberapa penyimpangan dari peraturan undangundang sekitar persatuan harta kekayaan. asal perjanjian itu tidak menyalahi tata susila yang baik atau tata tertib umum dan asal diindahkan pula segala ketentuan dibawah ini.

KUHPerdata juga jelas mengatur perjanjian perkawinan harus dibuat dihadapan notaris sebagaimana diatur dalam Pasal 147 KUHPerdata. UUP tidak secara jelas memberikan definisi mengenai perjanjian perkawinan. Dalam Pasal 29 UUP ayat (1) mengatur sebelum perkawinan berlangsung dapat mengadakan perjanjian tertulis yang disahkan oleh pegawai Pencatat Perkawinan. Dalam Penjelasan pasal tersebut dinyatakan perjanjian yang dimaksud tidak termasuk tak'lik talak. Pasal 29 ini juga tidak mengatur mengenai apa yang boleh diperjanjikan oleh suami-isteri. Menurut Prof.Wahyono Darmabrata. unsurunsur perjanjian perkawinan adalah: ${ }^{10}$

1) Perjanjian perkawinan dibuat oleh calon suami isteri sebelum perkawinan berlangsung. sebagaimana dinyatakan dalam Pasal 139 KUHPerdata dan Pasal 29 ayat (1) UUP.

2) Dibuat dalam bentuk tertulis. Pasal 147 KUHPerdata mengatur perjanjian perkawinan dibuat dalam akta notaris. Sedangkan dalam UUP Pasal 29 perjanjian perkawinan dapat dibuat di bawah tangan. Menurut Prof. Wahyono. sebaiknya perjanjian perkawinan dalam Pasal 29 tersebut harus dibuat dihadapan notaris. karena perjanjian itu juga berlaku bagi pihak ketiga.

3) Unsur Kesusilaan dan Ketertiban Umum . diatur dalam Pasal 139 KUHPerdata dan Pasal 29 ayat (2) UUP.

4) Unsur tidak boleh diubah. perjanjian perkawinan setelah perkawinan berlangsung tidak dapat diubah dengan cara bagaimanapun sebagaimana diatur dalam Pasal 149 KUHPerdata dan Pasal 29 ayat (4) UUP. Walaupun terdapat sedikit perbedaan yaitu menurut UUP perjanjian dapat diubah dengan persetujuan kedua belah pihak dan tidak merugikan pihak ketiga.

10 Wahyono Darmabrata, "Tinjauan Undang-Undang No.1 Tahun 1974 tentang Perkawinan beserta Undang-Undang dan Peraturan Pelaksanaannya", (Jakarta: CV. Gitama Jaya, 2003), hal. 82. 
Unsur Berlakunya Perjanjian Perkawinan. Perjanjian perkawinan berlaku setelah perkawinan berlangsung. seperti dinyatakan dalam Pasal 147 KUHPerdata dan Pasal 29 ayat (3) UUP.

\section{Menurut Hukum Islam}

Hukum Perikatan Islam adalah bagian dari hukum Islam bidang muamalah yang mengatur perilaku manusia dalam menjalankan hubungan ekonominya." Menurut H.M.Tahir Azhary Hukum Perikatan Islam adalah.

Merupakan perangkat kaidah hukum yang bersumber dari Al-Quran. as-Sunnah dan Ar-Ra'yu (ijtihad) yangmengatur tentang hubungan antara dua orang atau lebih mengenai suatu benda yang dihalalkan menjadi objek transaksi. ${ }^{12}$

Dari pengertian tersebut. tampak adanya kaitan yang erat antara Hukum Perikatan (yang bersifat hubungan perdata) dengan prinsip kepatuhan dalam menjalankan ajaran agama Islam yang ketentuan-ketentuannya terdapat dalam sumber-sumber hukum Islam tersebut. ${ }^{13}$

Ada dua istilah dalam Al-Quran yang berhubungan dengan perjanjian, yaitu $a l$-'aqdu (akad) dan $a l-$ ' $^{\prime} h d u$ (janji). Pengertian akad secara bahasa adalah ikatan. mengikat. Dikatakan ikatan (alrabih) maksudnya adalah menghimpun atau mengumpulkan kedua ujung tali dan mengikatkan salah satunya pada yang lainnya hingga keduanya bersambung dan menjadi seperti seutas tali yang

${ }^{11}$ Gemala Dewi. Wirdyaningsih. Yeni Salma Barlinti, "Hukum Perikatan Islam di Indonesia”, (Jakarta: Kencana, 2005). hal. 3.

12 M Tahir Azhary, Bahan Kuliah Hukum Perikatan Islam di fakultas Hukum Universitas Indonesia tanggal 16 februari 1998 dalam Gemala Dewi. et.al., "Hukum Perikatan Islam di Indonesia”, (Jakarta: Kencana. 2005), hal. 3.

13 Ibid. hal. 4. 
satu. ${ }^{14}$ Menurut Fathurrahman Djamil. istilah al-aqdu ini dapat disamakan dengan istilah verbintennis dalam KUHPerdata. ${ }^{15}$

Para ahli hukum Islam memberikan definisi akad sebagai: ${ }^{16}$

Pertalian antara ijab dan kabul yang dibenarkan oleh syara' yang menimbulkan akibat hukum terhadap obyeknya.

Fathurrahman Djamil mengemukakan ada tujuh asas yang berkaitan dengan Hukum Perikatan Islam. ketujuh asas tersebut. sebagai berikut: ${ }^{17}$

1. Asas Ilahiah, maksudnya adalah setiap tingkah laku dan perbuatan manusia tidak akan luput dari ketentuan ALLah SWT. Sebagaimana disebutkan dalam QS. alHadiid(57):4. yang artinya: "Dia bersama kamu dimana saja kamu berada. Dan Allah Maha melihat apa yang kamu kerjakan". Kegiatan muamalat. termasuk perikatan. tidak akan pernah lepas dari nilai-nilai ketauhidan. sehingga menimbulkan tanggungjawab bagi manusia.

2. Asas Kebebasan (al-hurriyyah), yaitu Islam memberikan kebebasan kepada pihak untuk melakukan suatu perikatan. Bentuk dan isi perikatan tersebut ditentukan oleh para pihak. Namun kebebasan ini tidak absolut. sepanjang tidak bertentangan dengan syariah Islam. maka. perikatan tersebut boleh dilakukan. Dasar hukumnya. yaitu QS al-Maaidah (5): 1 yang artinya. "Hai orang-orang yang beriman. penuhilah aqad-aqad itu".

3. Asas Persamaan atau Kesetaraan (Al-Musawah), setiap manusia memiliki kesempatan yang sama untuk melakukan suatu perikatan. Tidak boleh ada kezaliman yang dilakukan dalam perikatan tersebut.

${ }^{14}$ Ibid., hal. 45 .

${ }^{15}$ Fathurrahman Djamil, Hukum Perjanjian Syariah, dalam Kompilasi Hukum Perikatan oleh Mariam Darus Badrulzaman, dalam Gemala Dewi, et.al, "Hukum Perikatan Islam di Indonesia", (Jakarta: Kencana, 2005), hal. 45.

${ }^{16}$ Op. Cit., hal. 46.

${ }^{17}$ Djamil, Op. Cit., hal. 30. 
4. Asas Keadilan (Al-'Adalah), adil adalah sifat Allah yang sering disebutkan dalam al-Qur'an. Bersikap adil seringkali Allah tekankan kepada manusia dalam melakukan perbuatan. karena adil menjadikan manusia lebih takwa. Keadilan tidak dapat disamakan dengan persamaan. Dalam asas ini para pihak yang melakukan perikatan dituntut untuk berlaku benar dalam pengungkapan kehendak dan keadaan. memenuhi perjanjian yang mereka buat dan memenuhi semua kewajibannya.

5. Asas Kerelaan (al-Ridho), dalam QS an Nisa (4):29 dinyatakan segala transaksi yang dilakukan harus atas dasar suka sama suka atau kerelaan masing-masing pihak. tidak boleh ada tekanan. paksaan. penipuan. Unsur ini menunjukkan itikad baik dari para pihak.

6. Asas Kejujuran dan Kebenaran (Ash-Shidq), kejujuran merupakan hal yang harus dilakukan oleh manusia dalam segala bidang kehidupan. Jika kejujuran tidak diterapkan dalam perikatan maka akan merusak legalitas perikatan itu sendiri.

7. Asas Tertulis (Al-Kitabah), dalam QS al-Baqarah: 282283. disebutkan ALLah SWT menganjurkan kepada manusia hendaknya suatu perikatan dilakukan secara tertulis. dihadiri oleh saksi-saksi. dan diberikan tanggung jawab individu yang melakukan perikatan dan yang menjadi saksi.

Unsur-unsur akad adalah: ${ }^{18}$

a. Pertalian Ijab dan kabul. ijab dan kabul ini harus ada dalam setiap perjanjian. ljab adalah pernyataan kehendak salah satu pihak (muıjib) untuk melakukan sesuatu atau tidak melakukan sesuatu. Kabul adalah pernyataan menerima atau menyetujui kehendak pihak munijib tersebut oleh pihak lainnya.

b. Dibenarkan oleh syara, akad tidak boleh bertentangan dengan ketentuan Allah SWT dalam Al-Quran dan nabi Muhammad SAW dalam al-Hadits. Jika bertentangan maka mengakibatkan akad tersebut tidak sah.

c. Mempunyai akibat hukum terhadap objeknya. 
Islam mengenal apa yang disebut dengan janji kawin. Janji kawin menurut Hukum Islam adalah ta'lik talak. Ta'lik talak ini bertujuan untuk melindungi kepentingan wanita agar isteri tidak sia-sia dan teraniaya oleh perbuatan dan tingkah laku suami. ${ }^{19}$

\section{Menurut Kompilasi Hukum Islam}

Perjanjian perkawinan dalam Islam diatur dalam KHI Pasal 45 yaitu:

Kedua calon mempelai dapat mengadakan perjanjian perkawinan dalam bentuk:

1. Taklik talak; dan

2. Perjanjian lain yang tidak bertentangan dengan hukum Islam.

Pengaturan terbanyak dari perjanjian perkawinan adalah berkenaan dengan kedudukan harta dalam perkawinan. ${ }^{20} \mathrm{Hal}$ tersebut dapat kita lihat dibeberapa pasal yaitu Pasal 47 sampai dengan Pasal 50. Dari pasal-pasal dalam KHI yang mengatur mengenai perjanjian perkawinan ini. yang dimaksud perjanjian perkawinan adalah taklik talak dan perjanjian lain. Kata "perjanjian lain" dalam KHI tersebut yang menjadi dasar dapat dibuat perjanjian selain taklik talak yang mengatur mengenai kepentingan pihak-pihak yang membuat perjanjian sepanjang sesuai dengan Hukum Islam. Pasal-pasal yang mengatur mengenai perjanjian pekawinan ini cukup banyak mulai dari Pasal 45 sampai dengan Pasal 52. lebih banyak dari UUP yang hanya mengatur mengenai perjanjian perkawinan dalam satu pasal. ${ }^{21}$ $\mathrm{KHI}$ juga mengatur mengenai beberapa hal yang dapat diperjanjikan yaitu mengenai harta dalam pasal 47 sampai Pasal 50 dan mengenai tempat kediaman. waktu giliran. dan biaya rumah tangga bagi isteri dalam hal suami berpoligami. sebagaimana dinyatakan dalam pasal $52 \mathrm{KHI}$. Pelanggaran atas

${ }^{19}$ Zakiah Daradjat, "Ilmu Fiqh", (Yogyakarta: Dana Bhakti Wakaf), 1995, hal. 93.

${ }^{20}$ Abdurrahman, "Kompilasi Hukum Islam", (Jakarta: CV Akademika Presindo 2004), hal. 72.

${ }^{21}$ Ibid. 
perjanjian perkawinan memberi hak kepada isteri untuk meminta pembatalan nikah atau mengajukannya sebagai alasan gugatan perceraian ke Pengadilan Agama. hal ini diatur dalam Pasal 51 KHI.

Dalam penerapan perjanjian perkawinan terdapat perbedaan pendapat antara ulama mazhab Syafi'i. Hanafi. Maliki dan Hambali. Perjanjian itu sebagai berikut: ${ }^{22}$

1. Perjanjian tentang kewajiban suami terhadap isteri seperti pakaian. nafkah dan rumah kediaman. sepakat para ulama perjanjian ini wajib dipenuhi oleh suami.

2. Perjanjian tentang suami harus menceraikan lebih dulu isteri yang ada untuk melangsungkan perkawinan yang baru. Para ulama sepakat ini tidak wajib dipenuhi. karena ada larangan dari Nabi merubuhkan rumah tangga yang ada.

3. Perjanjian yang menyatakan bahwa mas kawin tidak akan dibayar suami. nafkah tidak diberikan suami. isteri tidak mendapat giliran sama. isteri yang akan menafkahi suami. para ulama sepakat perjanjian batal karena tidak sah.

4. Perjanjian yang bersifat kawin sementara (nikah mut'ah) atau yang dinyatakan setelah bersetubuh boleh bercerai (nikah muhallil) atau diperjanjikan dimana suami terlebih dahulu agar mengawinkan anak wanitanya dengan wali si wanita tanpa mas kawin (nikah syighar). Perjanjian ini batal dengan sendirinya karena tidak sah.

Menurut Zakiah Daradjat. apabila dalam akad nikah. atau tegasnya di dalam perkawinan diperbuat suatu janji yang bertentangan dengan syariat Islam. atau bertentangan dengan hakekat perkawinan. apapun bentuk perjanjian itu. perjanjian itu tidak sah. tidak perlu diikuti. Sedang akad nikahnya sendiri sah. ${ }^{23}$ Dasarnya adalah kata-kata Nabi Muhammad SA W: ${ }^{24}$

22 Mahmud Junus. Hukum Perkawinan dalam Islam. dalam Endang Sumiarni. "Kedudukan Suami Isteri dalam Hukum Perkawinan (Kạian Kesetaraan Jender Melalui Perjanjian Kawin)". (Jakarta: Wonderful Publishing Company, 2004), hal. 79.

${ }^{23}$ Daradjat, Op. Cit., hal. 93.

24 Ibid. 
Segala syarat yang tidak terdapat di dalam Kitabullah adalah batal. sekalipun seratus kali syarat muttafaq' Alalh.

\section{Pengertian Anak Sah}

\section{Menurut Hukum Islam}

\section{1) Pengertian Anak Sah}

Ada tiga hal yang dapat menetapkan kesahan seorang anak dari bapaknya menurut syariat Islam, yaitu. ${ }^{25}$

\section{Hubungan Suami Isteri yang Terjadi dalam Perkawinan yang Sah}

Sekalipun telah terjadi akad nikah yang sah antara seorang laki-laki dengan seorang wanita. namun perkawinan yang sebenarnya barulah terjadi bila suami isteri telah melakukan hubungan sebagai suami istri (coitus). ${ }^{26} \mathrm{Jika}$ dari hubungan itu isteri hamil. kemudian melahirkan anak. maka anak yang lahir adalah anak sah dari kedua suami isteri tersebut. Kesahan anak tersebut tidak memerlukan pengakuan maupun pembuktian, dasarnya ialah hadits:

Bersabda Rasulullah SAW: anak itu milik yang empunya tikar (suami) dan bagi pezina (dikenal) hukum rajam.

Maksud hadits diatas ialah anak itu milik suami ibunya (bapak). sedang bagi pezina itu adalah hukuman rajam dan anak yang lahir dari hasil perzinaan itu tidak mempunyai asal keturunan (bapak). ${ }^{27}$ Termasuk dalam pengertian hubungan suami isteri ialah pertemuan antara sperma suami dengan ovum isteri di dalam rahim ibu maupun di luar rahim ibu, seperti inseminasi buatan, yaitu memasukkan sperma suami ke dalam rahim isteri dengan

${ }^{25}$ Op. Cit., hal. 131.

${ }^{26}$ Ibid.

${ }^{27}$ Ibid, hal. 132. 
suatu alat atau dengan cara bayi tabung. Proses tersebut boleh saja asal ovum dan sperma suami isteri tersebut telah terikat dalam perkawinan yang sah.

Untuk mengetahui secara hukum apakah anak dalam kandungan berasal dari suami ibu atau bukan. ditentukan melalui masa kehamilannya. masa yang terpendek adalah enam bulan. hal ini merupakan kesepakatan para ulama. Pendapat itu berasal dari Ibnu Abbas yang berdasarkan AlQuran yang kemudian dibenarkan oleh khalifah Utsman bin Affan. $^{28}$ Sebagaimana dalam surat al-Ahqaf(50):15, yang artinya:

Kami perintahkan kepada manusia supaya berbuat baik kepada dua orang ibu bapaknya. ibunya mengandungnya dengan susah payah (pula). mengandung sampai menyapihnya adalah tigapuluh bulan...

Masa maksimum kehamilan menurut pendapat ulama berbeda-beda. Menurut Syi'ah masa hamil maksimum ialah 9 bulan atau 10 bulan. menurut Hanafi dua tahun. menurut Syafi'i 4 tahun. sedang menurut Maliki 5 tahun. Persoalan ini timbul jika seorang suami mentalak isterinya. dan setelah jatuh talak isterinya melahirkan. Apakah anak itu anak bekas suaminya atau bukan. Maka para ulama sepakat. apabila anak itu lahir paling lama setelah sembilan bulan atau sepuluh bulan dihitung sejak saat jatuhnya talak. maka anak itu adalah anak bekas suaminya.

Sahnya anak ditentukan oleh syarat-syarat sebagai berikut: ${ }^{29}$

1. Isteri mungkin hamil, bahwa dalam masa perkawinan. isteri melahirkan anak dalam keadaan sempurna setelah enam bulan setelah dilangsungkan akad nikah dan telah terjadi coitus. karena para ulama sepakat masa hamil minimum adalah enam bulan.

Is thid., hal. 133.

${ }^{29}$ Ibid. 
2. Masa hamil maksimum, jika diperhatikan lama masa hamil umumnya maka sebenarnya masa hamil minimal enam bulan dan maksimal 10 bulan itu adalah masa yang biasa terjadinya.

3. Tidak ada bantahan atau gugatan terhadap anak yang lahir, yaitu bantahan dari pihak suami yang menyatakan bahwa anak yang lahir itu bukan anaknya.

Nasab anak dalam Hukum Islam selalu kepada bapaknya. firman Allah SWt dalam surah Al-Ahzab(33):5:

Panggillah anak-anak dengan nasab (garis keturunan) ayah-ayah mereka.demikian itulah yang lebih adil menurut Allah...

Ayat tersebut berkaitan dengan ayat sebelumnya yang menentukan bahwa pengangkatan anak dengan jalan adopsi tidak dapat dibenarkan sebab berakibat keluarnya seseorang dari garis keturunan ayah kandungnya dan masuknya kepada nasab orang yang mengangkatnya. ${ }^{30}$

Berdasarkan ayat tersebut diperoleh ketentuan anak selalu bernasab kepada ayah. tidak kepada ibu. Berbeda dengan hubungan ibu dengan anaknya. hubungan bapak dengan anaknya tergantung pada adanya perkawinan atau tidak adanya perkawinan antara ibu sianak dengan laki-laki tersebut. ${ }^{31}$ Seruan al-Qur'an kepada umat manusia dengan panggilan wahai anak Adam memberi isyarat menisbahkan keturunan anak adalah kepada ayah. bukan kepada ibu. Sehingga dari uraian diatas jelas. anak sah adalah anak yang terlahir dalam perkawinan yang sah atau terlahir sesuai dengan ketentuan yang wajar dalam suatu pernikahan dan memiliki nasab dengan ayahnya.

Salah satu tujuan yang hendak dicapai oleh agama Islam dengan mensyariatkan perkawinan ialah lahirnya seorang anak sebagai pelanjut keturunan. bersih keturunannya. jelas bapaknya dengan perkawinan ibunya. Karena itu syariat Islam melarang segala perbuatan yang dapat menyebabkan

${ }^{30}$ Basyir, Op. Cit., hal. 105.

31 Neng Djubaedah, Sulaikin Lubis, Farida Prihartini, "Hukum Perkawinan di Indonesia", (Jakarta: PT. Hecca Mitra Utama, 2005), hal. 176. 
tidak jelasnya bapak seorang anak. seperti perbuatan zina. dan segala perbuatan yang mengarah kepada keadaan tersebut.

Dengan demikian syariat Islam menganut kemurnian nasab yaitu. menjadikan tetap dan jelasnya bapak seorang anak yang dilahirkan menjadi hak anak itu dan juga menjadi hak bagi bapak. ibu. dan seluruh keluarganya.

\section{Pengakuan}

Ada beberapa syarat pengakuan sehingga pengakuan itu menjadi sah, yaitu:

a. Jika orang yang diakui sebagai anak atau anggota keluarga itu adalah orang yang tidak diketahui keturunannya. Jika diketahui keturunannya. maka pengakuan itu tidak lagi beralasan.

b. Terdapat hal-hal yang mungkin membenarkan pengakuan itu. seperti ada persamaan bentuk antara bapak dengan orang yang diakui sebgai anaknya. atau perbedaan umur yang cukup antara kedua orang itu sehingga mungkin dikatakan bahwa anak itu adalah si bapak yang mengakuinya.

c. Anak itu bukan anak zina. atau anak itu bukan hasil perzinaan. Anak menurut agama Islam hanya timbul dari perkawinan bukan dari perzinaan.

d. Baik yang diakui atau yang mengakui saling membenarkan pengakuan itu dan orang yang mengakuiitu adalah orang yang mumayyiz dan dapat dipercaya pengakuannya. ${ }^{32}$

\section{Pembuktian}

Jika seseorang menyatakan ia anak si fulan atau cucu si A dan sebagainya. tetapi pernyataannya tidak dibenarkan oleh pihak yang lain. pernyataan itu harus disertai dengan alatalat bukti. Alat bukti itu berupa persaksian dua orang lakilaki atau seorang laki-laki dan dua orang perempuan.

32 Daradjat. Op. Cit., hal. 136. 


\section{2) Kedudukan Anak Sah}

Kedudukan anak sah dalam Islam. seorang anak sah akan mempunyai hubungan nasab dengan bapaknya baik secara biologis maupun secara hukum. Akibat dari hubungan nasab ini maka anaknya akan mempunyai hubungan kekeluargaan dan kewarisan dengan kedua orang tuanya. Kedua orang tuanya terutama bapak wajib memberi nafkah kepada anaknya. Kedua orang tua wajib memelihara anaknya dengan sebaik-baiknya. Bagi anak perempuan ketika ia akan menikah. bapaknya atau keluarga dari bapaknya yang laki-laki dapat menjadi wali. Antara anak sah dengan kedua orangtuanya merupakan mahram atau yang tidak boleh dinikahi oleh orangtuanya.

\section{Menurut Undang-Undang Perkawinan}

\section{1) Pengertian Anak Sah}

Mengenai anak. UUP mengaturnya dalam 4 (empat) bab. Pengertian anak sah diatur dalam bab IX Pasal 42 yaitu: Anak yang sah yaitu anak yang dilahirkan dalam atau sebagai akibat perkawinan yang sah.

Berdasarkan definisi tersebut setidaknya ada dua bentuk kemungkinan anak sah lahir akibat perkawinan yang sah dan anak yang lahir dalam perkawinan yang sah. ${ }^{33}$

Bentuk pertama anak yang lahir akibat perkawinan yang sah. ini sejalan dengan syari'at hukum Islam bahwa anak sah ialah anak yang dilahirkan sebagai hasil dari hubungan suami isteri dan terikat dalam suatu pernikahan yang sah. Bentuk yang kedua anak sah adalah anak yang terlahir dalam perkawinan yang sah. ketentuan ini menimbulkan interpretasi bahwa dapat terjadi seorang wanita telah hamil dulu lalu menikah dan ia melahirkan anak dalam pernikahan itu. Ini tentu saja tidak sejalan dengan ketentuan syariat Islam yang mendefinisikan anak sah adalah anak yang lahir sebagai akibat perkawinan yang sah. Hal ini secara implisit bahwa undang-undang 
melegalkan perbuatan yang dilakukan oleh laki-laki dan wanita diluar ikatan pernikahan.

Jika dibandingkan dengan hukum barat. Pasal 250 KUHPerdata. yaitu:

Tiap anak yang dilahirkan atau ditumbuhkan sepanjang perkawinan. memperoleh suami sebagai bapaknya.

Jika dilihat definisi pasal tersebut diatas. maka bentuk kedua dari definisi anak sah menurut UUP memiliki kesamaan dengan yang diatur oleh KUHPerdata.

\section{2) Kedudukan Anak Sah}

UUP mengatur kedudukan anak sah dalam beberapa pasal. Jika terjadi perceraian maka orang tua tetap berkewajiban memelihara dan mendidik anak-anaknya (Pasal 41 huruf a), Bapak bertanggungjawab atas semua biaya pemeliharaan dan pendidikan anaknya. bila bapak tidak sanggup memenuhi kewajiban tersebut, maka undangundang mengatur bahwa pengadilan dapat menentukan ibu ikut memikul biaya tersebut (pasal 41 huruf b). Orangtua yang sah wajib memelihara anak mereka dan jika mereka melalaikan kewajiban terhdap anaknya maka kekuasaan mereka sebagai orang tua dapat dicabut (Pasal 49 ayat (1)). Walaupun kekuasaan orang tua tersebut telah dicabut. mereka tetap berkewajiban untuk memberi biaya pemeliharaan anak (Pasal 49 ayat (2)).

\section{Menurut Kompilasi Hukum Islam}

\section{1) Pengertian Anak Sah}

KHI mengatur definisi anak sah dalam Pasal 99. yaitu Anak yang sah adalah:

a) Anak yang dilahirkan dalam atau akibat perkawinan yang sah:

b) Hasil pembuahan suami istri yang sah di luar rahim dan dilahirkan oleh isteri tersebut. 
Ternyata definisi anak sah menurut $\mathrm{KHI}$ sama dengan UUP. Pada UUP tidak ada penjelasan lebih lanjut terhadap definisi anak sah. sehingga ada penafsiran yang berbeda terhadap definisi tersebut. KHI pada Pasal 53 mengatur bahwa seorang wanita hamil luar nikah dapat dikawinkan dengan pria yang menghamilinya tanpa menunggu kelahiran anaknya terlebih dahulu. dan perkawinan tersebut tidak perlu dilakukan ulang setelah anak yang dikandung lahir. Jika dikaitkan dengan definisi anak sah di atas maka anak yang dilahirkan oleh wanita hamil tersebut merupakan anak sah. Pasal ini bertujuan untik melindungi kepentingan ibu dan anak. yaitu ibu menjadi tenang karena ada yang bertanggung terhadap dia dan anaknya. sementara dari sisi psikologis anak. anak akan tumbuh dengan baik karena tidak membawa beban berat yang harus ditanggungnya akibat perkataan orang lain yang tidak baik karena statusnya sebagai anak luar kawin. KHI memperluas definisi anak sah dengan mengikuti perkembangan teknologi seperti yang dinyatakan dalam pasal tersebut huruf b. Dengan demikian jelas anak yang dihasilkan dari pembuahan suami isteri yang sah diluar rahim dan dilahirkan oleh isteri tersebut bukan dari penyewaan atau penggunaan rahim dari perempuan lain. maka ia merupakan anak sah. Ini memungkinkan bagi suami isteri yang tidak dapat mempunyai anak dengan cara normal. Adanya ketentuan ini juga untuk melindungi kepentingan anak yang dilahirkan. Mengenai pengingkaran anak diatur dalam Pasal 101 KHI. Pengingkaran anak dilakukan oleh suami dengan mengajukan gugatan ke pengadilan agama diatur dalam Pasal 102. Pembuktian asal usul anak diatur dalam Pasal $103 \mathrm{KHI}$.

\section{2) Kedudukan Anak Sah}

Segala biaya penyusuan anak merupakan tanggung jawab ayah (Pasal 104). Jika ayahnya telah meninggal dunia. maka biaya tersebut dibebankan kepada orang yang berkewajiban memberi nafkah kepada ayahnya atau walinya. Perlindungan terhadap anak sah setelah perceraian diatur dalm Pasal 105 yaitu pemeliharaan anak yang belum mumayyiz atau belum berumur 12 tahun adalah hak ibunya. Jika anak tersebut sudah mumayyiz maka diserahkan 
kepada anak untuk memilih antara ayah atau ibunya yang akan merawatnya. Biaya pemeliharaan merupakan tanggung jawab ayahnya. KHI juga mengatur mengenai hak-hak anak sah dalam waris mewaris dalam bab kewarisan.

\section{Pengertian Anak Luar Kawin}

\section{1) Arti Zina Menurut Hukum Islam}

Al-Jurzani dalam kitabnya al-Ta'rifat. mendefinisikan zina: $^{34}$

Memasukkan zakar kedalam faraj yang bukan miliknya (bukan istrinya) dan tidak ada unsur syubhat (keserupaan atau kekeliruan).

Imam Taqiyuddin dalam Kitab "Kifayatul Akhyar" menyatakan bahwa: ${ }^{35}$

...zina yang dapat mendatangkan hukuman hadd tersebut adalah memasukkan hasyafah dari kelamin laki-laki ke faraj yang diharamkan.

Dalam "Fiqih Syafi'i" edisi bahasa Indonesia, Idris Ahmad menjelaskan bahwa: ${ }^{36}$

Zina adalah persetubuhan antara laki-laki dan perempuan di luar pernikahan. atau persetubuhan yang dilakukan tidak dengan nikah yang sah.Zina itu baru dapat dikatakan zina apabila seseorang memasukkan kemaluannya ke dalam kemaluan perempuan.

Berdasarkan definisi tersebut dapat diketahui perzinaan itu adalah suatu perbuatan yang dilakukan oleh mereka yang

${ }^{34}$ Safiudin Shidik, "Hukum Islam Tentang Berbagai Persoalan Kontemporer". (Jakarta:Intimedia. 2004), hal. 125.

${ }^{35}$ Djamil, Op. Cit.. hal 101.

${ }^{36}$ Asyahari Abdul Ghofar. "Pandangan Islam tentang Zina dan Perkawinan Sesudah IJamil”, cet. 3. (Jakarta:Andes Utama. 1993). hal.12. 
tidak terikat perkawinan yang sah yang memenuhi unsurunsur persetubuhan antara dua orang yang berbeda kelamin dan tidak adanya keserupaan atau kekeliruan. Hukum Islam membedakan zina dalam dua macam. yaitu zina Muhshan dan zina Ghoiru muhshan. ${ }^{37}$ Dikategorikan zina muhshan adalah zina yang dilakukan oleh orang yang telah atau pernah menikah. sedangkan zina ghoiru muhshan ialah zina yang dilakukan oleh orang yang belum menikah. Islam memasukkan perbuatan zina sebagai kejahatan tindak pidana yang pelakunya berhak mendapatkan hukuman yang berat. ${ }^{38}$ Ali Ahmad al -Jurjawi dalam bukunya Hikmah al Tasyri "wa Falsafatuhu yang dikutip oleh Masyfuk Zuhdi mengatakan, sedikitnya ada empat dampak negatif yang ditimbulkan dari perbuatan zina: ${ }^{36}$

a) Zina dapat mencemarkan kehormatan dan pencampuran nasab. Islam mengharamkan zina karena Islam sangat menjaga kesucian/kehormatan kelamin dan kemurnian nasab.

b) Zina dapat menularkan berbagai macam penyakit yang dapat mengancam kesehatan pasangan suami isteri yang berselingkuh (zina) dan akan mengancam keselamatan anak yang akan lahir.

c) Perzinahan dapat meretakkan sendi-sendi kehidupan keluarga dan bisa berakhir dengan perceraian. Sebab suami atau isteri yang melakukan zina dapat menimbulkan konflik yang besar dalam sebuah keluarga.

d) Perzinahan dapat menganiaya hak-hak anak yang tidak berdosa sebagai akibat dan ulah orang yang tidak bertanggungjawab. Karena di masyarakat anak zina sering di diskrit dan dimarjinalkan. Mereka diberi sebutan yang hina sebagai anak jadah/haram

${ }^{37}$ Sulaiman Rasjid. "Fiqh Islam", (Bandung:PT Sinar Baru Algensindo, 1994), hal. 436.

${ }^{38}$ Shidik, Op. Cit., hal. 141.

${ }^{39}$ Ibid. 
dan anak laknat. padahal mereka sebenarnya tidak berdosa".

Allah SWT dengan tegas mengharamkan perbuatan yang menuju kepada zina terlebih perbuatan zinanya, sebagaimana dalam firman-Nya:

Dan janganlah kamu mendekati zina; sesungguhnya zina itu adalah suatu perbuatan yang keji dan suatu jalan yang buruk.(QS al-Isra(17):32)

Oleh karena zina termasuk perbuatan yang keji . maka Islam memberikan sanksi hukuman yang berat kepada masing-masing pelakunya. Hal ini dijelaskan dalam firman Allah SWT:

Perempuan yang berzina dan laki-laki yang berzina. maka deralah tiap-tiap seorang dari keduanya seratus kali dera. dan janganlah kamu belas kasihan kepada keduanya mencegah kamu untuk (menjalankan) agama Allah. dan hari akhirat. dan hendakalah (pelaksanaan) hukuman mereka disaksikan oleh sekumpulan dari orang-orang yang beriman. (QS an$\operatorname{Nuur}(24): 2)$

Hukuman dera ini diberlakukan bagi pelaku zina yang belum menikah. Sedangkan bagi pelaku zina yang sudah menikah maka hukumannya lebih berat. yaitu dirajam sampai mati. Hal ini untuk memenuhi keadilan karena seharusnya orang yang sudah menikah itu bisa lebih menjaga kehormatannya. menjaga nama baik keluarganya dan masyarakat serta ia telah memiliki pasangan yang sah. ${ }^{40}$ Hukuman ini dijatuhkan pertama berdasarkan hadits Rasulullah dan praktek hukuman yang dilakukan oleh Ali bin Abi Thalib kepada Syarahah al- Hamdaniyah. Hadits Rasulullah berbunyi:." "pelaku zina yang telah menikah atau pernah nikah didera seratus kali atau dirajam."

Berdasarkan uraian di atas jelas bahwa Islam menganggap perbuatan zina adalah hubungan biologis yang dilakukan

40) Ibict.

"Ihid. hal. 132. 
diluar pernikahan. Perbedaan hukuman diberikan berdasarkan perbuatan zina untuk membedakan berat ringannya hukuman. tapi bukan untuk menentukan perbuatan itu termasuk zina atau bukan.

\section{2) Pengertian Anak Luar Kawin}

Para ulama ada mendefinisikan anak zina sebagai kontra anak yang sah sebagai berikut. ${ }^{42}$

Anak zina adalah anak yang dilahirkan ibunya dari hubungan yang tidak sah. Dan anak li'an adalah anak yang secara hukum tidak dinasabkan kepada bapaknya. setelah suami isteri saling meli an dengan sifat tuduhan yang jelas"

Definisi diatas membicarakan dua jenis status anak. Anak zina yang lahir dari hubungan yang tidak sah (zina) dan anak li'an. Hukum Islam menetapkan bahwa:

a) Seorang anak yang lahir selama enam bulan6) bulan dari hasil perkawinan adalah tidak sah;

b) Seorang anak yang lahir sesudah 6 (enam)bulan adalah sah;

c) Seorang anak yang lahir sesudah terputusnya perkawinan adalah sah jika lahir dalam jangka waktu sepuluh bulan (dalam hukum Syiah) atau sesudah jangka waktu dua tahun (hukum Hanafi)."

Hassanain Muhammad Makluf berpendapat;

Anak zina adalah anak yang dilahirkan ibunya dari hubungan yang tidak sah. Dan anak li'an ialah anak yang secara hukum tidak dinasabkan kepada bapaknya. setelah suami isteri saling meli'an dengan sifat tuduhan yang jelas. ${ }^{+3}$

${ }^{42}$ Fathurrahman Djamil, "Pengakuan Anak Luar Nikah dan Akibat Hukumnya", dalam "Problematika Hukum Islam kontemporer", Chuzaimah T Yanggo dan Hafiz Anshari Az (pd), (Jakarta:Firdaus, 1995), hal. 104.

${ }^{43}$ Ibid. 
Apabila terjadi perkawinan antar suami dan isteri secara sah. kemudian isteri mengandung dan melahirkan anaknya. maka suami dapat mengingkari kesahan anak itu apabila: ${ }^{44}$

a) Isteri melahirkan anak sebelum melahirkan dan

b) Melahirkan anak setelah lewat batas maksimal masa kehamilan dari masa perceraian

Dengan demikian dapat dikatakan apabila seorang isteri melahirkan anaknya kurang dari 6 (enam) bulan masa kehamilan. suami bisa mengajukan keberatan atas anak yang dilahirkan itu. Bahkan secara yuridis anak itu bukan lagi dianggap sebagai anak yang sah. Begitu pula seorang wanita yang telah dicerai kemudian melahirkan anak pada masa yang lebih dari sembilan bulan sampai satu tahun maka anak itu bukan anak dari suaminya.

Pengingkaran sahnya anak oleh suami dalam Islam dilakukan dengan sumpah li an (laknat). Arti kata li'an ialah sumpah laknat. yaitu sumpah yang didalamnya terdapat pernyataan bersedia menerima laknat Tuhan. ${ }^{45} \mathrm{Hal}$ ini dapat dilakukan apabila suami menuduh isteri berbuat zina. padahal tidak mempunyai saksi kecuali dirinya sendiri. Dasar hukum li'an adalah QS Nuur(24):6-9, yang menyatakan.

Para suami yang menuduh isteri mereka berbuat zina. padahal tidak mempunyai saksi kecuali diri mereka sendiri. hendaklah salah seorang di antara mereka menyatakan persaksian kepada Allah empat kali bahwa ia termasuk orang-orang yang benar...

Akibat dari sumpah li an suami adalah:

a) Suami dapat terhindar dari hukuman menuduh zina;

b) Dilakukan hukuman zina terhadap isteri;

c) Perkawinan putus;

d) Anak yang lahir bukan anak suami. hanya bernasab kepada ibunya;

${ }^{44}$ thid.

${ }^{45}$ Op. Cit. hal. 87. 
e) Isteri dapat menjadi haram selamanya terhadap suami tidak dapat kembali hidup bersuami isteri.

Dari penjelasan diatas jelas bahwa anak luar nikah menurut hukum Islam hanya memiliki hubungan nasab dengan ibunya saja.

\section{3) Kedudukan Anak Luar Kawin Dalam Hukum Islam}

Anak luar nikah hanya mempunyai hubungan hukum dengan ibunya atau keluarga ibunya saja. Permasalahan hukum yang timbul jika yang mengawini wanita hamil adalah bukan laki-laki yang menghamilinya, bagaimana status anak tersebut? Para ulama berselisih pendapat:

a) menurut Imam Malik dan Syafi'i. anak zina yang lahir setelah enam bulan dari perkawinan bapaknya. maka anak tersebut dapat dinasabkan kepada bapaknya. Karena diduga kuat perempuan itu telah melakukan zina namun tidak sampai pembuahan (hamil). Tapi jika anak itu lahir sebelum enam bulan maka dinasabkan kepada ibunya. Hal ini karena ada dugaan kuat si wanita telah melakukan hubungan seks dengan orang lain dan terjadi pembuahan. Mengapa dijadikan standar adalah enam bulan? Sebab paling kurang masa kehamilan itu adalah enam bulan.

b) Menurut Imam Abu Hanifah. anak zina tetap anak zina tetap dinasabkan kepada suami ibunya (bapaknya) tanpa mempertimbangkan waktu kehamilan si ibu. ${ }^{46}$

Permasalahan yang selanjutnya status anak jika yang mengawini perempuan hamil adalah laki-laki yang menghamilinya dengan cara zina, ada beberapa perbedaan pendapat:

a) Bayi itu termasuk anak zina. jika ibunya dikawini setelah kandungannya berumur empat bulan keatas. Jika kurang dari itu. maka bayi yang dilahirkan termasuk anak suaminya yang sah.

${ }^{46}$ Shidik, Op. Cit., hal. 134. 
b) Bila ibunya sudah hamil walau baru beberapa hari. kemudian dikawin oleh laki-laki yang menghamilinya. maka bayi yang dilahirkan bukan anak suaminya yang sah. Karena keberadaannya dalam kandungan mendahului perkawinan. maka anak tersebut termasuk anak zina.

Masalah yang ditimbulkan dari anak zina ini membawa kepada konsekuensi hukum selanjutnya yaitu:

a) Tidak ada hubungan nasab dengan laki-laki yang mencampuri ibunya secara tidak sah. Berdasarkan uraian tersebut bahwa anak sah dapat dihubungkan kepada bapaknya. Sedangkan anak luar kawin tidak dapat dihubungkan kepada bapaknya melainkan hanya dapat dihubungkan nasabnya kepada ibunya. Sehingga secara yuridis bapaknya tidak wajib memberi nafkah kepada anak itu. walau anak itu anak biologisnya.

b) Tidak ada saling mewarisi dengan laki-laki tersebut dan hanya salaing mewarisi dengan ibunya saja. Karena anak itu tidak memiliki hubungan nasab dengan bapaknya maka anak itu hanya dapat waris mewarisi dengan ibunya dan keluarga ibunya saja.

c) Tidak dapat menjadi wali jika anak yang lahir itu perempuan. dalam nikah. maka walinya adalah wali hakim.

\section{4) Menurut Undang-Undang Perkawinan}

UUP tidak mengatur secara jelas mengenai pengertian anak luar nikah. Tapi UUP mengatur mengenai kedudukan anak luar nikah sebagaimana dapat dinyatakan dalam pasal 43:

a) Anak yang dilahirkan di luar perkawinan hanya mempunyai hubungan perdata dengan ibunya dan kelurga ibunya.

b) Kedudukan anak tersebut ayat (1) di atas selanjutnya akan diatur dalam Peraturan pemerintah.

Pengaturan ini sejalan dengan hukum Islam bahwa anak luar nikah hanya mempunyai hubungan nasab dengan ibunya saja. UUP juga tidak mengatur mengenai pengakuan anak dan pengesahan terhadap anak luar nikah. 
Hal ini juga sejalan dengan syariat Islam bahwa dalam Islam tidak dikenal pengakuan anak sebagaimana dalam hukum barat. Pengakuan anak dalam hukum barat dimaksudkan agar anak luar nikah tersebut menjadi anak sah. Sedangkan dalam Islam tidak dikenal pengakuan anak dan disahkan anak luar kawin dengan akta seperti dalam hukum barat.

\section{5) Menurut Kompilasi Hukum Islam}

Pengaturan menganai anak luar nikah menurut $\mathrm{KHI}$ sama dengan UUP. $\mathrm{KHI}$ tidak memberi definisi jelas mengenai anak luar kawin. tapi hanya mengatur mengenai kedudukan anak itu. Pasal $100 \mathrm{KHI}$ menyatakan:"Anak yang lahir di luar perkawinan hanya mempunyai hubungan nasab dengan ibunya dan keluarga ibunya".

Tidak seperti pada UUP. KHI tidak menyebutkan akan ada pengaturan lebih lanjut mengenai anak luar kawin. Ini menunjukkan menurut $\mathrm{KHI}$ kedudukan anak luar kawin sudah jelas. sebagaimana dalam syari'at Islam. Mengenai pengingkaran anak diatur dalam Pasal 101 dan $102 \mathrm{KHI}$. yaitu suami dapat mengingkari sahnya anak dengan jalan li'an, jika istri tidak menyangkalnya. Pengingkaran tersebut diajukan ke Pengadilan Agama. Pembuktian asal usul anak diatur dalam pasal $103 \mathrm{KHI}$. yaitu asal usul anak dapat dibuktikan dengan akta kelahiran atau alat bukti lainnya. Pengaturan asal usul ini sama dengan Pasal 55 UUP.

\section{Analisis Kasus}

Kasus pada akta perjanjian perkawinan ini adalah. tuan $\mathrm{Y}$ dan nona $\mathrm{A}$ beragama Islam ingin mengadakan perkawinan. Sebelum perkawinan dilangsungkan sepakat untuk membuat perjanjian perkawinan dihadapan notaris. Perjanjian tersebut mengenai harta dan biaya rumah tangga. Permasalahan yang terjadi pada kedua calon suami isteri ini. yaitu tuan $\mathrm{Y}$ dan nona $\mathrm{A}$ telah memiliki anak yang dilahirkan sebelum perkawinan dilangsungkan. Berdasarkan kenyataan tersebut maka status anak yang dilahirkan adalah anak luar kawin (Pasal 272 KUHPerdata. Pasal 43 UUP. Pasal $100 \mathrm{KHI}$ ). Menurut KUHPerdata anak luar kawin dapat diakui oleh kedua orang tuanya sehingga status anak tersebut menjadi anak sah (Pasal 272). Pengakuan dilakukan dengan mengakuinya dalam akta perkawinan 
(Pasal 272). atau dapat juga dengan akta otentik (Pasal 281). Adanya pengakuan tersebut menyebabkan anak itu menjadi anak sah. sehingga ia memiliki hak-hak dan kedudukan yang sama dengan anak sah (Pasal 277) dan memiliki hubungan dengan kedua orang tuanya (Pasal 280). Islam tidak menganut pengakuan anak sebagaimana dalam KUHperdata. Karena kedua pasangan yang telah disebutkan di atas beragama Islam maka anak luar kawin tersebut tidak dapat diakui. Anak luar kawin dalam Islam disebut anak zina. Sehingga yang menjadi pertanyaan adalah dapatkah anak luar kawin menjadi tanggung jawab suami seluruhnya yang dimuat dalam perjanjian perkawinan terlebih dahulu dan bagaimana Hukum Islam menentukan hak anak luar kawin dalam akta perjanjian perkawinan.

Berdasarkan uraian teori. yang termasuk anak luar kawin atau anak zina adalah anak yang dilahirkan diluar perkawinan yang sah. Menurut hukum Islam anak luar kawin atau anak zina hanya memiliki hubungan nasab dengan ibunya saja. Mengingat anak tersebut tidak diakui dan disahkan sebagai anak sah. hak-hak dan kedudukan anak luar kawin tidak sama dengan anak sah. Jika anak sah. tanggung jawab mengenai biaya pemeliharaannya atau hadahanah merupakan kewajiban bapaknya. pada anak luar kawin tanggung jawab pemberian nafkah. biaya pemeliharaan merupakan tanggung jawab ibunya dan keluarga ibunya. Walaupun yang mengawini ibunya adalah bapak biologisnya tetapi bapaknya (suami ibunya) tersebut tidak wajib untuk menafkahi anaknya. Anak sah dapat saling mewaris dengan kedua orangtuanya. terutama dengan ayahnya karena ia memiliki hubungan nasab dengan bapaknya. Sedangkan anak luar kawin tidak dapat saling mewaris dengan kedua orangtuanya terutama dengan bapaknya. ia hanya dapat saling mewaris dengan ibunya dan keluarga ibunya saja.

Pasal 3 dalam perjanjian perkawinan yang dibuat dengan akta notaris menyatakan bahwa:

Segala biaya dan beban rumah tangga. demikian juga pemeliharaan anak dan pendidikan anak-anak yang dilahirkan dalam pernikahan suami isteri. merupakan beban tanggungan dari dan oleh karena itu harus dipikul dan dibayar oleh suami. adapun isteri tentang hal tersebut tidak diwajibkan memikul atau membayar biaya-biaya tersebut.

Agar suatu perjanjian sah. perjanjian tersebut harus memenuhi unsurunsur perjanjian. Salah satu unsur sahnya perjanjian dalam Islam adalah perjanjian tidak boleh bertentangan dengan sya'ra. Jika hal ini tidak dipenuhi maka perjanjian tersebut tidak sah. Salah satu asas dalam perjanjian dalam 
hukum Islam adalah kebebasan. dasar hukumnya ${ }^{47}$ QS al-Maaidah(5):1 yang artinya. "Hai orang-orang yang beriman. penuhilah aqad-aqad itu"

Kebebasan yang dianut bukan kebebasan yang mutlak. karena kebebasan tersebut dibatasi dengan agama. Perjanjian yang dibuat berlaku bagi pihak yang membuatnya dan harus ditaati selayaknya undang-undang. seperti diatur dalam Pasal 1338 KUHPerdata.

Ketentuan yang dinyatakan dalam akta tersebut sesuai dengan undangundang. juga sesuai dengan syari'at Islam dan KHI. Tapi ketentuan ini berlaku bagi anak sah. dan sebagai wujud dari bentuk tanggung jawab bapak terhadap anaknya. Bagaimana dengan anak luar kawin. bagaimana bentuk tanggung jawab seorang bapak yang dalam kasus ini merupakan ayah biologis dari anak yang dilahirkan.

Sesungguhnya anak yang dilahirkan ke dunia tidak berdosa. suci dan bersih. tanpa memandang orang tuanya. Islam mengakui hal tersebut berdasarkan hadits yang diriwayatkan oleh Imam al-Baihaqi: ${ }^{48}$

Setiap anak yang lahir ke dunia ini suci dan bersih (dari dosa) dan beragama tauhid. sehingga ia jelas bicaranya. Maka kedua orangtuanyalah yang menyebabkan anaknya beragama Yahudi atau nasrani atau Majusi.

Maka. upaya apa yang harus dilakukan untuk melindungi kepentingan anak dalam kasus ini. Mengingat Islam tidak mengakui pengakuan anak sebagaimana dalam hukum barat. masalah ini menjadi cukup rumit. Pada dasarnya setiap pihak bebas membuat perjanjian dan menentukan isi perjanjian tersebut sepanjang tidak bertentangan dengan undang-undang. norma kesusilaan dan kepatutan.

Islam tidak mengakui pengakuan anak terhadap anak luar kawin sehingga walau sang bapak merupakan ayah biologis anak tersebut. ia tidak wajib untuk memberi nafkah kepada anaknya. Akan tetapi. demi kepentingan anak dan masa depannya. dianjurkan bagi bapaknya untuk membiayai pemeliharaan dan pendididikan anaknya tersebut. Pemberian nafkah kepada anak luar kawin dari bapak biologisnya merupakan suatu perwujudan

${ }^{47}$ Fathurrahman Djamil, "Hukum Perjanjian Syariah, dalam Kompilasi Hukum Perikatan”, oleh Mariam Darus Badrulzaman, dalam Gemala Dewi, et.al., "Hukum Perikatan Islam di Indonesia", (Jakarta:Kencana, 2005), hal. 249.

${ }^{48}$ Shidik, Op. Cit., hal. 139. 
tanggung jawab atas perbuatan yang telah dilakukan oleh kedua orang tuanya. Maka. sudah seharusnya laki-laki yang menghamili wanita di luar nikah memberikan nafkah kepada anak dari hasil hubungannya tersebut. walau menurut agama ia tidak wajib untuk melakukannya. Jadi tidak berarti anak tersebut dapat dinasabkan kepada bapaknya. tetapi pemberian nafkah tersebut merupakan bentuk dari rasa kemanusiaan dan kepatutan.

Mengingat dalam hal ini pemberian nafkah kepada anak luar kawin tidak merupakan suatu yang dilarang oleh undang-undang maupun agama. dapat diperjanjikan bahwa seorang bapak yang memiliki anak luar kawin dapat memberi nafkah kepada anak tersebut. Hal ini dapat dilakukan sepanjang bapak bersedia memberi nafkah dan segala biaya pemeliharaan dan pendidikan anaknya. Islam tidak mengenal anak angkat. atau mengakui anak orang lain sehingga menjadi sah tetapi Islam sangat menganjurkan untuk mengasuh anak yatim dan anak terlantar. Hal ini ditunjukkan dengan beberapa firman Allah SWT. sebagai berikut ${ }^{49}$

QS al-Baqarah(2):215, yang artinya:

Mereka bertanya kepadamu tentang apa yang mereka nafkahkan. Jawabla: "apa saja harta yang kamu nafkahkan hendaklah diberikan kepada ibu-bapak.kaum kerabat. anakanak yatim. orang-orang miskin dan orang-orang yang sedang dalam perjalanan.

QS al-Baqarah(2):220, yang artinya:

Tentang dunia akhirat. Dan mereka bertanya kepadamu tentang anak yatim. katakanlah: "mengurus urusan mereka secara patut adalah baik. dan jika kamu menggauli mereka. maka mereka adalah saudaramu dan Allah mengetahui siapa yang membuat kerusakandari yang mengadakan perbaikan. Dan jikalau Allah menghendaki. niscaya Dia dapat mendatangkan kesulitan kepadamu. Sesungguhnya Allah Maha perkasa lagi maha Bijaksana.

QS an-Nisaa'(4):36, yang artinya;

Sembahlah Allah dan janganlah kamu mempersekutukan-Nya dengan sesuatu pun. Dan berbuat baiklah kepada dua orang

${ }^{49}$ Departeman Agama RI. Al-Quran dan terjemahannya. 
ibu-bapak. karib kerabat. anak-anak yatim. orang-orang miskin. tetangga yang dekat dan tetangga yang jauh. teman sejawat. ibnu sabil dan hamba sahayamu.Sesungguhnya Allah tidak menyukai orang-orang yang sombong dan membanggabanggakan diri.

Oleh karena itu. dalam akta perjanjian perkawinan. demi kepentingan anak luar kawin tersebut di dalam akta dinyatakan (Pasal 3) bahwa:

Segala biaya dan beban rumah tangga. demikian juga biayabiaya pemeliharaan dan pendidikan anak-anak yang dilahirkan dalam pernikahan suami isteri. atau yang dilahirkan sebelum perkawinan dan disahkan dalam perkawinan suami isteri menurut peraturan yang berlaku. merupakan beban tanggungan dari dan oleh karena itu harus dipikul dan dibayar oleh suami. adapun isteri tentang hal tersebut tidak diwajibkan memikul atau membayar biaya-biaya tersebut.

Kalimat "...dan yang disahkan menurut peraturan yang berlaku..." pada akta tersebut tidak seharusnya ada. Karena dalam Islam tidak dikenal pengesahan anak. Oleh karena itu pada akta perjanjian perkawinan bagi yang beragama Islam kalimat terebut tidak perlu dimuat dalam akta.

Kelemahan lain dalam akta tersebut adalah tidak dicantumkannya nama anak luar kawin pasangan tersebut agar jelas kepada siapa biaya pemeliharaan dan pendidikan tersebut diberikan. Dalam akta tersebut juga tidak dinyatakan. demi kepentingan anak luar kawin tersebut. ia berhak mendapatkan kasih sayang dari kedua orang tuanya terutama bapaknya selayaknya anak sah. Mengingat anak luar kawin tidak dapat mewaris dengan bapaknya. dalam akta tidak diatur mengenai pemberian lain sebagai alternatif dari mewaris yaitu. pemberian hibah saat bapaknya masih hidup atau pemberian wasiat kepada anak luar kawin saat bapaknya meninggal.

Dengan demikian mengenai tanggung jawab bapak terhadap anak luar kawin. sepanjang bapak bersedia untuk bertanggung jawab membiayai dan memberikan nafkah kepada isteri dan anaknya tersebut dan merawat. memberikan kasih sayang terhadap anak luar kawin tersebut. Maka. demi kepentingan anak luar kawin. anak tersebut berhak mendapatkan haknya selayaknya anak sah. 


\section{Penutup}

\section{A. Kesimpulan}

Berdasarkan uraian kasus diatas. maka dapat ditarik kesimpulan. yaitu:

1. Anak luar kawin dapat menjadi tanggung jawab suami ibunya apabila ada kerelaan dan dapat dimuat dalam perjanjian perkawinan. Ini memenuhi salah satu asas perikatan dalam Hukum Islam yaitu asas kerelaan. Ketentuan dalam akta perjanjian perkawinan Pasal 3 yang menyatakan tanggung jawab terhadap anak luar kawin. yaitu dengan adanya pernyataan bahwa suami bertanggung jawab atas segala nafkah rumah tangga dan biaya pemeliharaan dan pendidikan anak baik anak yang dilahirkan dalam perkawinan atau yang dilahirkan sebelum perkawinan.

2. Dalam akta perjanjian perkawinan dapat diperjanjikan anak luar kawin memperoleh biaya pemeliharaan dan pendidikan dari suami ibunya. yang merupakan ayah biologisnya. Akan tetapi akta ini tidak mencantumkan nama anak luar kawin tersebut agar jelas kepada siapa biaya pemeliharaan dan pendidikan tersebut diberikan. akta ini juga tidak mengatur pemberian lain sebagai bentuk pertanggungjawaban ayah terhadap anaknya yaitu kasih sayang selayaknya kepada anak sah. Mengingat anak luar kawin tidak dapat mewaris dengan bapaknya. dapat diperjanjikan pemberian wasiat kepada anak tersebut jika bapaknya meninggal atau pemberian hibah saat bapaknya masih hidup.

\section{B. Saran}

Pada dasarnya setiap anak yang dilahirkan ke dunia dilahirkan dlam keadaan suci dan bersih. Orang tua dari anak tersebut yang membedakan anak-anaknya dengan anak yang lain. sehingga tidak sepatutnya seorang anak ditelantarkan. Dalam kasus sudah seharusnya menjadi tanggung jawab bapak untuk membiayai anaknya. Hal-hal yang perlu diperhatikan antara lain:

1. Ketentuan mengenai definisi anak luar kawin harus dimuat dalam UUP dan KHI. agar jelas yang dimaksud dengan anak luar kawin. sehingga definisi itu dapat dibedakan dengan definisi anak sah agar tidak terjadi perbedaan penafsiran. 
2. Hal-hal khusus yang mengatur mengenai kedudukan. status dan tanggung jawab terhadap anak luar kawin sebaiknya dimuat dalam undang-undang agar kedudukannya lebih kuat.

3. Terhadap masyarakat agar disosialisasikan mengenai tanggung jawab terhadap anak luar kawin. Sehingga masyarakat mengerti dan tidak membedakan anak luar kawin dengan anak sah. Pensosialisasian ini juga bertujuan agar masyarakat menyadari tanggung jawabnya terhadap anak-anak terlantar sehingga dapat mengurangi jumlah anak terlantar akibat perbuatan kedua orang tuanya.

4. Calon suami isteri yang memiliki anak luar kawin dan hendak menikah sebaiknya membuat perjanjian perkawinan yang mengatur mengenai tanggung jawab terhadap anak luar kawin untuk melindungi kepentingan anak luar kawin tersebut.

5. Sebaiknya perjanjian perkawinan yang dibuat. mengatur lebih lengkap mengenai hak anak luar kawin yang lainnya seperti layak mendapatkan kasih sayang dari orang tuanya. Mengingat anak luar kawin tidak dapat mewaris dengan bapaknya sebaiknya diatur juga mengenai pemberian wasiat jika bapaknya meninggal atau pemberian hibah jika bapaknya masih hidup. 


\section{Daftar Pustaka}

Abdul Ghofar, Asyahari., Pandangan Islam tentang Zina dan Perkawinan Sesudah Hamil, Cet. 3, Jakarta: Andes Utama, 1993.

Abdurrahman, Kompilasi Hukum Islam, Jakarta: CV. Akademika Presindo, 2004.

Abu Zahrah, Muhammad, al Ahwal al Syakhisiyyah dalam Amir Nuruddin dan Azhari Akmal Tarigan, Hukum Perdata Islam di Indonesia studi kritis perkembangan Hukum Islam dari Fikih, UU no. 1 tahun 1974 sampai KHI, Jakarta: Kencana 1999.

Azhar Basyir, Ahmad., Hukum Perkawinan Islam, Yogyakarta: UII Press, 1999.

Azhary, M. Tahir., Bahan Kuliah Hukum Perikatan Islam di fakultas Hukum Universitas Indonesia tanggal 16 februari 1998 dalam Gemala Dewi, et.al. Hukum Perikatan Islam di Indonesia, Jakarta: Kencana, 2005.

Daradjat, Zakiah., Ilmu Fiqh, Yogyakarta: Dana Bhakti Wakaf, 1995.

Darmabrata,Wahyono., Tinjauan Undang-Undang No.1 Tahun 1974 tentang Perkawinan beserta Undang-Undang dan Peraturan pelaksanaannya, Jakarta: CV. Gitama Jaya, 2003.

Djamil, Fathurrahman., Hukum Perjanjian Syariah. dalam Kompilasi Hukum Perikatan oleh Mariam Darus Badrulzaman. dalam Gemala Dewi et.al. Hukum Perikatan Islam di Indonesia, Jakarta: Kencana 1998.

, Hukum Perjanjian Syariah. dalam Kompilasi Hukum Perikatan oleh Mariam Darus Badrulzaman, dalam Gemala Dewi, et.al. Hukum Perikatan Islam di Indonesia, Jakarta: Kencana, 2005.

, Pengakuan Anak Luar Nikah dan Akibat Hukumnya, dalam Problematika Hukum Islam Kontemporer, Chuzaimah T. Yanggo dan Hafiz Anshari Az (pd), Jakarta: Firdaus. 1995.

Dewi, Gemala, Wirdyaningsih, Yeni Salma Barlinti. Hukum Perikatan Islam di Indonesia, Jakarta:Kencana, 2005.

Djubaedah, Neng, Sulaikin Lubis, Farida Prihartini., Hukum Perkawinan di Indonesia, Jakarta: PT. Hecca Mitra Utama, 2005.

Junus, Mahmud., Hukum Perkawinan dalam Islam. dalam Endang Sumiarni. Kedudukan Suami Isteri dalam Hukum Perkawinan (Kajian Kesetaraan Jender Melalui Perjanjian Kawin), Jakarta: Wonderful Publishing Company, 2004. 
Rasjid, Sulaiman., Fiqh Islam, Bandung: PT. Sinar Baru Algensindo, 1994.

Safiudin, Shidik., Hukum Islam Tentang Berbagai Persoalan Kontemporer, Jakarta: Intimedia, 2004.

Subekti., Pokok-Pokok Hukum Perdata, Jakarta: PT. Intermasa, 1993.

Wahbah, Zuhaily., al-Fiqh al-Islami Wa Adilatuhu dalam Amir Nuruddin dan Azhari Akmal Tarigan. Hukum Perdata Islam Di Indonesia Studi Kritis Perkembangan hukum Islam dari Fiqh, UU no. 1/1974 sampai KHI, Jakarta: Kencana.

Widjaja, IG Rai., Merancang Suatu Kontrak Contract Drafting Teori dan Praktik, Jakarta: Kesaint Blanc, 2002. 